\title{
Post-Communist Memory Culture and the Historiography of the Second World War and the Post-War Execution of Slovenian Collaborationists
}

\author{
OTO LUTHAR \\ Slovenian Academy of Sciences and Arts
}

\begin{abstract}
Summary
This paper aims to summarize the transformations in contemporary Slovenia's post-socialist memorial landscape as well as to provide an analysis of the historiographical representation of The Second World War in the Slovenian territory. The analysis focuses on the works of both Slovenian professional and amateur historiographical production, that address historic developments which took place during the Second World War and in its immediate aftermath from the perspective of the post-war withdrawal of the members of various military units (and their families) that collaborated with the occupiers during the Second World War.
\end{abstract}

Keywords: Slovenes, Partisans, Home Guards, Historiography, Memory

\section{Introduction}

The debate on post-communist/post-socialist historical interpretation has become an inseparable part of the new politics of the past across Eastern and Southeastern Europe. In Slovenia, the once-vivid historiographical debate on the nature of historical explanation has been ever since largely overshadowed by new attempts to monopolize historical interpretation. The discussion, that has been led from the 1980s onwards, has brought forward new forms of historical representation which have once again given way to the politicized reinterpretation of the most disputed parts of the Second World War and the subsequent time of socialism. Like in some other parts of post-socialist Europe, the past has become a "morality drama" and a "pas- 
sion play, combining high ideology and down-and-dirty politics". ${ }^{1}$ Consequently, the anticipated democratization and modernization of historical interpretation have been obstructed by (at least) two processes: firstly, by the nationalization of history/ the past and, secondly, by the struggles for a new political monopolization of a particular version of historical interpretation.

The latter also includes a radical change in the memorial landscape. No other country in the region has witnessed such a profound change in its material memorial landscape as Slovenia. ${ }^{2}$ This is particularly true of the creation of monuments dedicated to Slovenian collaborators during the Second World War. Since 1991, more than two hundred monuments praising collaborators as the true victims of the war have been erected. ${ }^{3}$ Members of the resistance and victims among the civilian population, on the other hand, are represented as part of the "communist revolution" and as members of the Partisans, who waged "war against their own people" (Dežman, 2004). According to Jože Dežman, the chairman of the governmental commission for the mass graves, "the group of the dead", which before that enjoyed the "Party heaven", was joined by a group that during socialism was consigned to the "Party hell".

This is why, when discussing post-socialist historical revisionism and negationism in Slovenian historiography, we cannot overlook the changes of the memorial landscape in general. Changes have also occurred in remembering all those who

1 Like Eva Hoffman in "Hearing Poland's Ghosts" (The New York Review of Books; Volume LXV, Number 5; pp. 4-8), I too would like to stress the importance of the recent manifestation of war and post-war history's significance, either through the creation of new museums and monuments or through the impact of new politics of the past. The only difference between the Polish case described by Hoffman and the situation in Slovenia is the fact that the Slovenian past could be investigated, re-examined and debated already before 1989 .

${ }^{2}$ Here, I am primarily referring to the setting up of new monuments rather than the destruction of those commemorating the fallen Partisans and the revolution. Namely, until recently, very few monuments have been destroyed in Slovenia, and even these were most often spray-painted. Serious damage was caused to no more than five newly erected monuments, and by the end of 2017, more than 230 new monuments were built to honor the Home Guards who lost their lives during the war or died in post-war killings, as well as other members of collaborationist units.

3 The term "parish plaques" in reference to Home Guard monuments was introduced by a group of people who organized the installation of monuments in parish cemeteries in central Slovenia. Among them were also some active members of the collaborating Home Guard units established under the Nazi command after the capitulation of Italy. As the plaques were placed on the chapels of parish cemeteries, the term refers to factual locations. What remains unclear is the connection between the initiators and local communities. In any event, the installation of the plaques evoked at once support and contention. Some supporters were not satisfied with the politicization of the project while others were interested in an even more direct confrontation with (if present) already existing Partisan monuments. 
withdrew into Austria alongside the German army units. Among the refugees, there were also many collaborators' family members. Even though most of them made their retreat over the Ljubelj mountain pass, a growing number of historiographical sources make mention of Bleiburg and its surroundings. The clashes that erupted between the Partisans and the retreating Domobranci, Ustaše, and Četniks along this section of the border just before and after the armistice were of even greater consequence for the subsequent fate of the border than a peaceful retreat over the Ljubelj pass.

\section{Historiography}

The focus of this article, however, will be on professional historiography, although all books and articles of historians I have included in my analysis do not fit the description of usual academic historiographical works. The majority of them are actually closer to (popular) essays and literary reflections than to monographs or scholarly articles. This does not mean that they are less important. On the contrary, they are in fact far more influential than well-researched scholarly works by the same authors. With regard to their influence, I have tried to arrange them in one of the following four groups of writings that have shaped the post-socialist politics of the past in Slovenia.

(1) A typical example of essayistic historiography is the reader The Dark Side of the Moon, edited by Alenka Puhar, Vasko Simoniti, and Drago Jančar. Although given their age, the editors could be the admirers of the famous Pink Floyd album, there is no evidence to support this. The book is too dark to be compared with one of the greatest rock and roll albums of all times. Instead of following the inspiring lyrics of Us and Them ("God only knows it's not what we would choose to do..."), most of the authors were inspired by the narrative of Black Book of Communism, edited by Stéphane Courtois, while the title is taken from Edvard Kocbek's novel Temna stran meseca. ${ }^{4}$

The book was accompanied by a homonymous exhibition, both being praised as "Slovenia's step closer to the European civilization space" (Dnevnik, December 18, 2008). Jože Dežman, who authored this statement, is not only the most remarkable revisionist historian in Slovenia but also the author of two books that share

${ }^{4}$ Edvard Kocbek (1904-1981) was a Slovenian poet, writer, essayist, translator, member of Christian Socialists in the Liberation Front of the Slovenian Nation and Partisan resistance in the Second World War. He is considered to be among the best Slovenian poets. His political work during and after the war made him one of the most controversial figures in twentieth-century Slovenia. His novel The Dark Side of the Moon has nothing to do with the conflict between resistance and collaboration, although it was published in a book (Strah in pogum/Fear and Courage; together with three other novels) that deals with this topic as well. 
the narrative of the Dark Side. His rhetoric is likewise typical of numerous (at least $2,000)$ newspaper articles dealing with this topic. ${ }^{5}$

(2) Dežman is also the best representative of the so-called therapeutic historiography. According to Aviezer Tucker, revisionist historiography often "relies on therapeutic values instead of the standard consensus-generating cognitive values that historians of diverse backgrounds agree on. Therapeutic values rate historiographical propositions according to their effect on the psychological well-being of their intended audience" (Tucker, 2008: 15). ${ }^{6}$ Authors such as Dežman are inclined to use highly metaphorical language underlining the terms and slogans like "Slovenian cities of the dead"; Slovenia is "the killing field of Europe"; and the communists being possessed by "the God complex", which articulates in their "racist division of the dead and the living".

As already stressed by Tucker, the therapeutic interpretation of the past often relies on "the denial of historical guilt" and "supports the promotion of self-respect... via national myths". And finally, it relies on the elimination of a sense of alienation and absurdity, for instance, through conspiracy theories in which the conspirators were the communists and the post-war communist regime. After 1991, the communists became post-communists and "the biggest criminals and murderers" who remained in control of "all social channels, from education, media, culture, to civil society" (Jaklitsch, 2016: 10). This is, among others, one of the central topics in the quarterly Zaveza, "the journal for spiritual, cultural and political questions of the present and the past - with a special emphasis on the crisis of Slovenian-hood after the Bolshevik revolution and the Civil War". The authors who write for this journal and systematically follow the motto of the editorial mostly focus on the remnants of the "Bolshevist machinery" (Rihar 2016: 1), "communist crimes" and "burying the dead (collaborators)" (Jaklitsch, 2016: 10), and the "allowed" and "un-

${ }^{5}$ After looking through the archives of ten daily and weekly newspapers for the period between 1994 and 2008 (more than 800 articles and comments), I have found that a majority of them were published in the main Slovenian newspapers Delo (more than 200) and Večer (120), followed by the weekly Družina, issued by the Slovenian Catholic Church (more than 80), and the right-wing journal Demokracija (66).

${ }^{6}$ Like Tucker, I too believe that historiography founded on therapeutic values promotes a series of national historiographical myths and that there will always be a "market for therapeutic historiography because people and their institutions will always pay to promote, read, or hear therapeutic accounts of their collective or, for that matter, personal past" (Tucker, 2008: 17).

${ }^{7}$ Interview with Jože Dežman in Delo (Albreht), May 24, 2006 and with Mitja Ferenc in Večer, October 30, 2004 (Žunec). In his interview for the biggest Slovenian daily (Delo), Dežman speaks of more than 400 graves and some 200 that have not yet been unveiled. More moderate members of the commission like Mitja Ferenc speak of 390 known killing sites and some 130 that probably still wait to be discovered. 
allowed collaboration" (Rihar 2016a: 115). Convinced that Slovenia is witnessing a renewed "praise for the socialist past" (Senegačnik, 2016: 7) and that "the greatest (communist) killers were presented as national heroes" (Jaklitsch, 2016: 11), they systematically translate collaborators into "innocent victims being killed" (ibid.: 9). Even more so, one of the founders of the journal refers to the Partisans as terrorists. Previously using the term "Bolshevik guerilla", he now claims that the resistance movement was actually a series of terrorist acts. The narrative of "criminals - heroes" vs. "Slovenian martyrs" and "the struggle between civilization and barbarity" is followed by the claims that what happened in Slovenia was not the Partisan resistance against the occupying Nazis and Fascists and their collaborators, but a civil war that ended with "genocide and exodus" (Sušnik, 2016: 92-93). Instead of facts and analysis, the authors call for "common sense" and "putting things in their right place" (ibid.: 91). After twenty-five years of its existence, the journal's program remains unchanged, presenting Nazi and Fascist collaborators as "the real rebels, who opposed communism". One of the results of this re-interpretation is the transformation of new sites of remembrance into the realm of over-identification. One of the long-term consequences of Slovenian therapeutic historiography is thus also the future-oriented interpretation of the past in general. Therefore, amidst the current situation in Slovenia, the need for a "middle voice" is even greater than in other parts of post-socialist Europe. Particularly if we understand it as a way to articulate historical experience in a mode that remains... faithful to the witness's perspective, without confusing structural for historical trauma", and the "absence for loss" (Crownshaw, Kilby, and Rowland, 2011: 12).

(3) The lesser known and unjustly neglected interpretation of the collaboration is represented in mostly self-published works by former Home Guards (Domobranci), or members of the Village Sentries. The majority of these works are personal narratives describing historical developments, as well as some examples in which the authors bring their accounts into confrontation with the communist interpretation of the Second World War. A typical example of such literature is the work written by a Home Guard from Lower Carniola, Ivan Horvat, titled Borbe $v$ Suhi krajini marca 1943 (The Battles in Suha krajina in March 1943). The book was self-published in 2011, just before the author's death. Authors who fought with the Home Guards, and remained in Slovenia after the war, confined their narratives to military activities and basic descriptions of the circumstances surrounding recruitments into Partisan and Home Guard units. On the other hand, Home Guards who retreated into Carinthia or Friuli Venezia Giulia and later emigrated also delved into ideational questions, with education playing an important part in the process, as well as the fact that they did not live in Slovenia after 1945. A somewhat more equilibrated interpretation was presented by contemporary critics of the "communist" resistance 
movement who remained in Slovenia after the war and interpreted wartime developments from the perspective of the post-war period. One interesting example is the work written by Peter Starič, Moje življenje v totalitarizmu 1941-1991. Nenavadna življenjska pot inženirja elektronike (My Life in Totalitarian Regime 19411991. Extraordinary Life of an Electric Engineer). Despite the title promising an exhaustive description of the events that took place during the Second World War, the author does not limit himself to providing a comprehensive description of life in Yugoslav "totalitarianism", but also mentions the post-war killings of German captives, Četniks, Ustaše, and Slovenian Home Guards. As most authors in this group, he is challenging the interpretation that describes the members of collaborationist units as traitors. In his view, the victims uncovered at the sites of post-war killings are not perpetrators but merely victims and he avoids literature that portrays them as Nazi and Fascist collaborators (Tone Ferenc, Janko Pleterski, Metod Mikuž, Peter Vodopivec, Bojan Godeša, etc.). The two examples presented here account for only two of the three clusters of contemporary interpretations. What is still missing is the aforementioned works of contemporaries who emigrated and the interpretation of the Partisans whose subsequent memoirs also discuss the members of collaborationist units.

(4) The fourth group consists of the writings of authors with academic ambitions. The list is a rather long one, but the most important are the following historians, philosophers, a sociologist, and a jurist: Tamara Griesser-Pečar, Boris Mlakar, Janko Pleterski, Jurij Štesi, Katja Zupanič, Mateja Čok Kladnik, Damjan Hančič, Renato Podberšič, Milko Mikola, Božo Repe, Bojan Godeša, Tadeja Tominšek Rihtar, Marjan Žnidarič, Aleš Gabrič, Tine Hribar, Gregor Kranjc, and Ivan Kristan. Since some of them (Repe, Godeša, Hribar, Mlakar, Gabrič, Griesser-Pečar, Pleterski) are often referred to by the media, politicians, and other amateur interpreters of Slovenia's past, this group seems deserving of a little more attention. For an easier understanding of their sometimes extremely different interpretations of collaboration, I divided them into three subgroups:

\section{A}

Revisionist/negationist historiography, represented by authors from the Study Center for National Reconciliation or its external associates. The most prominent among them is Tamara Griesser-Pečar, with her books Razdeljeni narod, Rožmanov proces (Divided People, Rožmanov's Process) (in co-authorship with France Dolinar) and Med sodbo sodišča in sodbo vesti (Between the Judgment of Courts and the Judgment of Conscience) (in co-authorship with Marija Čipič, France Dolinar, Blaž Otrin, and Julijana Visočnik). Other external associates of note include the aforementioned Jože Dežman and Boris Mlakar, an employee of the Institute of 
Contemporary History. A group of lesser-known authors who deal with specific aspects of war or post-war history have adopted the Center's definitions of the resistance movement, collaborationists, and the post-war communist regime. ${ }^{8}$ Special mention should also be made of books on the post-war persecution of kulaks ${ }^{9}$ and political opponents. ${ }^{10}$

Founded by the right-wing government in 2008, the Study Center for National Reconciliation is still strongly supported by the Slovenian Democratic Party (SDS Slovenska demokratska stranka). ${ }^{11}$ Moreover, since the spouse of the vice-president (Milan Zver) and the closest associate of the president of the SDS (Janez Janša) is the head of the center, it is little wonder that the party's leadership takes part in all important events organized by this institution.

The common denominator in the narratives of historians working at the center is a systematical denial of the crimes committed by collaborators. In their revisionist interpretation of the Second World War and the years that followed, the authors like Dežman, Mlakar, and Pečar systematically ignore the victims of collaborators, not to mention the collaboration with the Nazis and Fascists. Therefore, they too are responsible for the creation of the passive identity of self-victimization (Assmann, 2013: 148-152), based on non-recognition of any shared responsibility for the committed crimes. What is more, the function of this self-victimization is not only running away from the responsibility of perpetrators, but also avoiding any "politics

8 Jurij Štesl, Pohorska afera (The Pohorje Affair); Katja Zupanič, Četništvo na Štajerskem (The Chetnik Movement in Styria); Damjan Hančič, Revolucionarno nasilje na vzhodnem Gorenjskem 1941-1945 (Revolutionary Violence in Eastern Upper Carniola 1941-1945); Damjan Hančič, Revolucionarno nasilje v Ljubljani, 1941-1945 (Revolutionary Violence in Ljubljana, 19411945); Renato Podberšič, Revolucionarno nasilje na Primorskem 1941-1945 (Revolutionary Violence in the Littoral 1941-1945).

9 Mateja Čoh Kladnik, Kulaški procesi v Sloveniji med letoma 1949 in 1951 (The Kulak Processes in Slovenia between 1949 and 1951).

${ }_{10}$ Milko Mikola, Dokumenti in pričevanja o povojnih izgonih prebivalstva v Sloveniji (Documents and Testimonies about Expulsions in Slovenia after World War II); Milko Mikola, Dokumenti in pričevanja o povojnih koncentracijskih taboriščih v Sloveniji (Documents and Testimonies about Concentration Camps in Slovenia after World War II); Milko Mikola, Celje v plamenih revolucije (Celje in the Flames of Revolution).

11 The center was established by the right-wing Janez Janša government (2004-2008), headed by the Slovenian Democratic Party. First (2005) it was initiated as a "sector within the Ministry of Justice... responsible for the recognition of injustices and reconciliation". Three years later, it was reorganized into a public research institution (the Study Center for National Reconciliation) focused on the analysis of "all three totalitarian regimes". According to historian Peter Vodopivec, a leading expert in the modern history of Slovenia, it subsequently "became hostage to the rightwing political parties and their pragmatic demand for an uncompromising condemnation of 'communist totalitarianism"” (Vodopivec, 2016: 52). 
of remorse" (Assmann, 2013) and the "narrowing of memory" (Engfuehrung des Gedaechtnisses). The culture of self-victimization they are looking for is thus based not only on revision but on absolute negation of historical facts. A fine example of this is the single visit that Franjo Tuđman paid to the memorial park of Jasenovac in 1996, where he laid a wreath to commemorate as much "the victims of Fascism and NDH as those executed by the communist regime" (Radonic, 2009: 176). The ensuing polemic flared up not only over this hurtful comparison but also because some newspapers likened Tuđman's visit to Jasenovac to Willy Brandt's honoring the victims of the Warsaw Ghetto.

This also includes a complete ignorance of the deportation and destruction of the Slovenian Jewish community, as well as the distinctly anti-Semitic ideology of collaborators. From the Domobranci perspective, "the Partisans were drugged and bought by Jews in order to make them destroy the Slovenian nation, while on the side of the Slovenian Domobranci stands a German soldier fighting against worldwide Jewry" (Lešnik and Tomc, 1995: 124).

After the exclusion of their killings of Partisans and their relatives and the victims of the Fascist and Nazi occupation, the revisionists display collaborators as a uniform group of victims of communist terror. In the new history of the Second World War and the "communist" period, resistance against the occupying forces is being interpreted as a "communist revolution" and a war "against its own people" (Dežman, 2004: 44-48).

From a methodological aspect, the ongoing "repackaging of history" (Dragosavac, 2013: 339) builds on a sort of descriptive self-sufficient mode of interpretation $^{12}$ of which selective positivism is the extreme form.

This narrative, always full of metaphors, is also slowly but persistently undermining the role of historians who have been traditionally regarded as providing the facts for "objective" interpretations. Here, the term objective is understood in the sense of "strategy of objectification" which, according to LaCapra, "induces a denial of transferential implication in the object of study and obviates the problem of actual". Such an objectifying strategy may "assume a radical divide between objectivity and subjectivity and lead to... obscuring the voices of the dead" (LaCapra, 2001: 39). By seeing the past merely in terms of contemporary uses, the revisionists/negationists not only eliminate "the diachronic weight of the past" but also

12 The term owes to Dominic LaCapra, who distinguishes between two approaches to historiography. The first is what he terms a documentary or self-sufficient research model, and the second - which is the negative mirror of the first one - is that of radical constructivism. The second one has received its most articulate defenders in such important figures as Hayden White and Frank Ankersmit, who accept the distinction between historical and fictional statements on the level of reference to events, but question it on the structural level. See LaCapra, 2001: 1-8. 
misuse the after-effect of trauma. This is what LaCapra would call the numbing of trauma. This kind of "historiography" cannot help to come to terms with the wound and the scars of the past. It does not seek knowledge, it does not empathetically expose the self, but sticks with a one-dimensional revision of the past.

Finally, mention should also be made of discussions written by individuals with no formal affiliation, whose works would subsequently be incorporated into collections kept by some public institutions or societies. The former type of collaboration is well exemplified by the work by Monika Kokalj Kočevar, Gorenjski domobranci (The Upper Carniola Home Guard), which the Museum of Upper Carniola in Kranj included in its collection "Places and People of Upper Carniola". The aforementioned work is indeed a well-researched text about Domobranci units from the Upper Carniola region, starting with the names of those who organized them. The problem is in the introduction written by Jože Dežman, who in the late 1990s started to claim that the Domobranci of Carniola were "on the fringe of the battlefield" and hence "on the fringe of violence". Moreover, before changing his mind completely and presenting them exclusively as victims, Dežman maintained that the Domobranci were the "scapegoats" who caught the brunt of hatred. Nonetheless, the work of Monika Kokalj Kočevar adds a valuable insight into the emergence, operations, and the final destiny of the Domobranci movement in Upper Carniola. The author managed to reconstruct the network of fifty posts accommodating about 3,500 men, who, along with Germans, left Slovenian territory in May 1945. Out of about 1,000 men who were sent back by the British authorities in Carinthia, 800 were killed.

One typical example of the latter type of collaboration is the book by Gregor Medvešček, Mit o NOB. Miti in resnice o narodnoosvobodilnem boju (The Myth about NOB. Myths and Truths about the People's Liberation Struggle), which was embraced by the Society for the Research of Recent History at OZNA. ${ }^{13}$ This work exemplifies discussions whose authors argue that "rather than Quislings, one can only talk about the counter-revolution in Slovenia" (Medvešček, 2010: 176), that "the underlying nature" of Slovenian collaboration was "the counter-revolution, which would not have taken place had it not been for the communist revolution" (ibid.: 177), and that the "anti-communist side... has been grossly discredited and even demonized by red propaganda" (ibid.: 280). According to these discussions, "red propaganda" prevents us "from taking a fresh look at wartime events in Slovenia" and hence "from reaching a reconciliation" (ibid.).

13 OZNA, or the Department for People's Protection, was the security agency of the Federal People's Republic of Yugoslavia and was founded on 13 May 1944. 
B

The second subgroup consists of authors who have tried to avoid the politics of the past and have been critical of both the one-dimensional interpretation of socialist historiography and the revisionist re-interpretation after 1991.

The most senior of this group is Janko Pleterski, an emeritus and a member of the Slovenian Academy of Sciences and Arts, who in his book Senca Ajdovskega gradca (The Shadow of Ajdovski gradec) and in numerous articles throws light on attempts to "convert collaboration into civil war", leading to the "symmetry of guilt" and "apologetic interpretation of collaboration" (Pleterski, 2007: 28). Another well-researched book is Od Pohlinove slovnice do samostojne države. Slovenska zgodovina od konca 18. do konca 20. stoletja (From Pohlin's Grammar to an Independent State. Slovenian History from the End of the 18th to the End of the 20th Century) by Peter Vodopivec. For the purpose of this article the most interesting chapter is the one concerning the period of the Second World War. Similar to Vodopivec's interpretation, the fate of Domobranci is described in The Land Between: A History of Slovenia, in which the post-war killing of the Home Guards is described as one of "the most tragic episodes in modern national history", which even seventy years after the Second World War "still polarizes the Slovenian political and intellectual public. This became all the more evident after the 2004 election, when the Slovenes found themselves caught between two different worlds nourishing two different ways of understanding their past and promoting two different perceptions of national interests" (Luthar, 2014: 437).

A similar interpretation can be found in the works of Bojan Godeša, probably the foremost authority on the Liberation Front. Among his works on this topic we have to stress the importance of Čas odločitve. Katoliški tabor in začetek okupacije (Decision Time. The Catholic Camps and the Beginning of the Occupation, 2011) and Kdor ni z nami, je proti nam. Slovenski izobraženci med okupacijo, Osvobodilno fronto in protirevolucionarnim taborom (Those Who Are Not With Us, Are Against Us. Slovenian EducatorsDuring the Occupation, the Liberation Front and the Counter-revolutionary Camp, 1995). Another earnest attempt to provide a synthesis is the book by Gregor Krajnc's To Walk With the Devil: Slovene Collaboration and Axis Occupation 1941-1945. Krajnc's description of the Home Guard ideology as "a blend of nationalism, Catholicism, anti-Communism and anti-Semitism", together with his reconstruction of the role of the Catholic Church, underscored by the quotation from Bishop Rožman's "memorandum", according to which "the Liberation Front... [was] the greatest danger to Christianity and for the Christian life of... [the] nation that had ever before existed in [its] 1,300-year history" (Kranjc, 2013: 103 ), is probably the best synthesis on this topic so far. 
In addition to the works listed above, there are an increasing number of analyses of individual processes and phenomena. A good example of such discussions is the article by Tanja Jokomin Kocijančič in Acta Histriae (Vol. 20, 2012, issue 4), titled Reprezentacija drugih $v$ domobranskem tisku v slovenskem Primorju 19441945 (Representation of the Others in the Home Guard Press in the Slovenian Littoral 1944-1945).

Like the authors who stand for the radical revision of the Second World War in Slovenia, the historians from this group influence some politicians and journalists in their criticism of "systematically erasing" and "devising a balanced version... of some history". The latter are especially critical of the so-called "converts", former members of the Communist Party who are now known for their radical anti-communism (Jež, 2016: 15).

C

The third cluster of authors are the ones Slovenian historian Nevenka Troha presents as "traditionalist", i.e., "historians" interested in "preserving the interpretation of the Liberation Movement" (Troha, 2017: 343). According to her analysis of the historical representation of the Second World War, "an important publication outlet" represents the "Partisan Book Club" series" (Partizanski knjižni klub), coordinated by the Association of Writers of the History of the National Liberation Struggle in Slovenia. She has identified "more than forty books" that "have been published in this series since 1992" (ibid.), although only one was published after 2010. In most cases, these are descriptive presentations of different Partisan units, occupation regimes, "military tactics, weapons, activities of the resistance in different regions, concentration camps and activities of the Slovenian Communist Party" (ibid.: 344). Another important asset of Troha's article is its emphasis on the scope of the historiographical approach to the Second World War and its aftermath. According to Slovenian Virtual Library (COBISS.SI), "the keywords druga svetovna vojna, Slovenija (the Second World War, Slovenia) provide 8,828 results which is, as she puts it, really "quite impressive". Nevertheless, this is one of the best researched topics, with no end in sight to this kind of thematic interest as Troha, too, believes that "many issues" still remain poorly researched or even un-tackled (ibid.: 362-363).

\section{D}

Finally, there is a list of monographs and articles whose authors speak of the civil war and lean towards the distribution of guilt. The position of these authors may in many regards be illustrated with the positions of those who defend national reconciliation or those who justify the need to "venerate all the dead" with the belief that "everyone killed" (Jogan, 2014: 115). Among the authors advocating this posi- 
tion one may find several non-historians, with the most typical representatives of such (re)interpretation being philosopher Tine Hribar and his wife, the sociologist Spomenka Hribar, the initiators of the idea of national reconciliation. Among the most notable historians belonging to this group is Mitja Ferenc, who is largely considered a "bone expert" (Jež, 2016: 15). One thing the authors in this group have in common is placing emphasis on the right to burial or invoking the ancient heritage, particularly Sophocles' Antigone. Interestingly, however, they too fail to draw a parallel with the ancient Ephialtes, who helped the Persians defeat the Greek Army at Thermopylae and may thus be regarded as a prototypical collaborator. But even more important than this is the one-sided, if not simplistic, reading offered by Tine and Spomenka Hribar. In their political interpretation of the plot, they overlook the complexity of the Greek drama of the "Athenian century" (Mendelsohn, 2016: 59). It seems that they intentionally miss the point of Sophocles' play, which is not about Antigone being "right" and Creon being "wrong", but rather that each character "has a valid point to make" (ibid.: 61). Even more so, they fail to see that Antigone and Agamemnon present "the irresistible spectacle of two world views" (ibid.). Because of their unwillingness to "weigh and compare the principles the characters adhere to" for their failure to "reflect on the necessity of seeing the whole and on the difficulties of keeping the parts of equilibrium, they cannot appreciate the cost of sacrificing some values of the others..." (ibid.).

As Tine and Spomenka Hribar's simplistic reading of Sophocles' Antigone became part of Slovenian revisionist narrative, people who are also interested in philosophical dimensions of the whole discussion miss the most important message of the play. By accepting the black-and-white translation of the conflict between Agamemnon and Antigone, they are unable to see that the "agonizing choices" offered by Sophocles are supposed to provide them with opportunities to reflect on their lives and the life of the society they belong to.

Like other cases of classifying interpretations of disputed processes and events, the classification at hand allows for certain authors to fall into several groups. This applies above all to the negationist interpretation of resistance and collaboration. Authors who stress the question of causality and responsibility of the collaborators and therefore condemn the distortion of historical truth do not refer to ancient references. And even though there seems to be no end to this particular debate, they are not very likely to write essays for a wider audience.

\section{Post-socialist Historical Experience Unlimited?}

As in some other parts of Southeastern Europe, in Slovenia too the new "cult of death" only includes the victims of communism or, at best, presents a framework for a revisionist competition of victimization. This systematic translation of perpe- 
trators into victims (Pavlaković in Jorgačević, 2015: 10) is, according to Assmann, based on the non-recognition of any shared responsibility for the committed crimes. What is more, the function of self-victimization is not only running away from the responsibility of perpetrators, but also avoiding any "politics of remorse" (Assmann, 2013: 148).

The collateral damage of this is, as already mentioned in the beginning, the declining idea of democratizing the interpretation of the past, which started in the early 1980s. The anticipated future development of post-socialist historiography has been suppressed by the "re-emergence of themes from the past" (Pavlaković in Jorgačević, 2015: 13). Efforts to embrace modern trends in historiography, the reconstruction of the past of marginalized (ethnic, gender, economic) groups, and especially endeavors for what Reinhart Koselleck called "history in the plural" have been replaced by the renewed exclusivist nationalization of historical interpretation. By this we refer to a new generation of university professors who completed their studies after the end of socialism and have realized that "the war and trauma (still) sell well" in former socialist countries (ibid.). This generation therefore finds it slightly harder to comprehend why those who obliterate the differences between perpetrators and victims often invoke national identity and the lack of "shared memory" (Leiler, 2015: 14).

The critics of this narrative openly stress that much like the war, occupation, collaboration and resistance constituted a process that marked a vast part of Europe, the current (changes in) commemorative practices are an all-European phenomenon as well. This is particularly the case with discussions on victims and perpetrators. Over the past decade, the latter have not only been the common denominator of political debates in Eastern, Central and Southeastern Europe, but have underlined the culture of remembering throughout the continent. Or, as Drago Roksandić put it, "all complexities that make up Europe find nowhere a more vivid expression than in Southeastern Europe".

The extent to which it is possible to agree with the statement above is illustrated by the examples of historical revisionism in Central Europe. According to Ferenc Laczo, the "New Europe", memories and remembering have become crucial for producing and understanding a series of phenomena in everyday life strategies that figure as fundamental driving forces in creating and reshaping contemporary individual, local, national, and transnational identities.

A similar opinion is expressed by authors who find that after the fall of socialism, the attempts to reach national reconciliation were coupled with radical reconfigurations and reinterpretations of the past to negotiate local, national, and transnational identities, and to strengthen national agendas. In most former socialist countries, historical interpretation significantly resembles the struggle over the 
legitimacy and authenticity of this representation. The revisionist approach to the past has become not only the site of struggles over the meanings of past events and structures but also a part of the new quest for the ideal "we" of the present. What appears to be a discussion about the past and a reconstruction of historical truth reveals more about the present fragility and plurality of identities and politics aimed at fixing the definition of national identity. In short, it is a struggle over interpretative resources within society.

The most recent Slovenian example of this sort is the newest monument to the "martyrs of the revolution" in Grahovo, ${ }^{14}$ calling for a complete change of historical roles. According to the inscription on the central part of the monument, the Partisans and some civilian victims of Fascism and Nazism are transformed into perpetrators. In a rhyme following the title, they all are challenged as "communists". Although remembered as "brothers by birth", they are condemned as "strangers by mind", while the collaborating Domobranci are presented as members of "the Slovenian National Army", waiting for the new "generation [to] break the false silence" and restore their "stolen honor and truth...".

The initiators (either historians or politicians) of this line of reinterpretation of the Second World War in Slovenia thus not only ignore the historical facts, but show that some historical interpretation actually can operate in isolation from the rest of society and therefore does not represent a common social practice.

The same goes for the memorial plaque installed on the fence of the US Embassy in Ljubljana a few months earlier. According to the bilingual inscription on it, the Nazi collaborators are presented as "Slovenians who sought peace" but "could not avoid war". Besides this, the plaque honors and celebrates all "those brave Slovenians who seek reconciliation" since they are the ones who "strive to preserve Slovenia's independence and identity".

Leaving aside the question of what to do with those who believe that there is no need for reconciliation - or even worse, that in Slovenia, the reconciliation narrative is being used to gain ground in everyday political disputes in which national reconciliation was hijacked for revisionist purposes, the US Mission openly interferes in the past of a hosting country.

In this way it shares the responsibility for the growing gap between historical interpretation and the politics of history. Instead of prompting the necessary

14 The monument was erected in 2014, close to where a battle began between Domobranci and the Partisans immediately following the capitulation of Italy. The initiators also chose Grahovo, a village located some $40 \mathrm{~km}$ southwest of Ljubljana, because the Partisans burned down the house in which the Home Guards were defending themselves and because one of the victims was a wellknown Slovenian poet, France Balantič, who joined the Home Guards in 1942. 
debate about the relationship between morality and politics, it supports the moralizing discourse that seriously influences the political life of the country. Even more so, Ambassador Joseph A. Mussomeli and his successors have become part of the interpretative model that completely ignores the international framework and the chronology of events before and during the war. By joining the revisionist interpretation, they have shown that they know how to make history despite being familiar with the past that enables it.

According to this, the Slovenian post-socialist historical experience seems to be marked by the double intrusion of the political. On the one hand, the new revisionist reinterpretation has narrowed historiography down to the politics of the past while, on the other, it has continuously neglected the plurality of political opinions. By ignoring the general public opinion, it might also be understood as a consequence of the crisis of the political, in which politics are being replaced by morality and history, where the latter happened to be conceived as a one-sided reinvention of the roles of victims and perpetrators. In doing this and by stressing the need for national reconciliation, the initiators and supporters of the revised version of the past have forgotten that in contrast to revenge, which is usually an automatic "reaction to transgression... the act of forgiving can never be predicted" (Arendt, 1998: 241). They also seem to have forgotten that acts of "[f]orgiving are not abstract moral measures, but rather arise from concrete experience and are achieved in the beingtogether of humans, the public space of the political".

\section{REFERENCES}

“Aktualni kulturnopolitični komentar revije Zaveza”. 2010. Zaveza, 78.

Arendt, Hannah. 1998. The Human Condition. University of Chicago Press. Chicago.

Assmann, Aleida. 2013. Das neue Unbehagen an der Erinnerungskultur. Eine Intervention. C.H. Beck Verlag. Munich.

Crownshaw, Richard; Kilby, Jane; Rowland, Anthony. 2011. The Future of Memory. Bergham Books. New York - Oxford.

Dežman, Jože. 2004. “Naj se zgodovina odpre”. Interview. Mag, 9-10: 44-48.

Dragosavac, Nebojša. 2013. “Prepakivanje istorije' masovnim preimenovanjem beogradskih ulica”, in: Samardžić, Momir; Bešlin, Milivoj, Milošević, Srđan (eds.): Politička upotreba prošlosti. O istorijskom revizionizmu na postjugoslovenskom prostoru. AKO. Novi Sad. 
Godeša, Bojan. 1995. Kdor ni z nami, je proti nam. Slovenski izobraženci med okupacijo, Osvobodilno fronto in protirevolucionarnim taborom. Cankarjeva založba. Ljubljana.

Godeša, Bojan. 2011. Čas odločitve. Katoliški tabor in začetek okupacije. Mladinska knjiga. Ljubljana.

Hoffman, Eva. 2018. "Hearing Poland's Ghosts". The New York Review of Books, Volume LXV, No. 5.

Jaklitsch, Helena. 2016. "Brez spomina". Zaveza, No. 100, XXVI. Nova slovenska zaveza. Ljubljana.

Jež, Boris. 2016. “Kaj je hujšega od komunizma? Antikomunizem”. Sobotna priloga, April 30.

Jogan, Maca. 2014. "Vrednotenje narodnoosvobodilnega boja in socializma v samostojni Sloveniji”, in: Stanovnik, Janez; Grča, Slavko; Kmecl, Matjaž; Pirjevec, Jože; Jogan, Maca; Kovač, Božo; Klavora, Mitja (eds.): Slovenski zbornik. Narodnoosvobodilni boj in današnji čas. Zveza združenj borcev za vrednote NOB Slovenije. Ljubljana.

Jorgačević, Jelena. 2015. "Pad imuniteta na fašizam". Vreme (Belgrade), No. 1282, July 30.

Kern, Ana Nuša; Nećak, Dušan; Repe, Božo. 2000. Naše stoletje: zgodovina za 8. razred osnovne šole (Our Century: History for the 8th Grade Primary School). Modrijan. Ljubljana.

Kopeček, Michal (ed.). 2008. Past in the Making. Central European University Press. Budapest.

Kranjc, Gregor. 2013. To Walk With the Devil. Slovene Collaboration and Axis Occupation 1941-1945. University of Toronto Press. Toronto - Buffalo - London.

Kuljić, Todor. 2002. Prevladavanje prošlosti. OH. Belgrade.

LaCapra, Dominick. 2001. Writing History, Writing Trauma. The John Hopkins University Press. Baltimore - London.

Leiler, Ženja. 2015. "Brane Senegačnik: 'Lahko se samo aklimatiziraš ali pa se izseliš’”. Delo (Ljubljana), July 25.

Lešnik, Doroteja; Tomc, Gregor. 1995. Rdeče in črno. Slovensko partizanstvo in domobranstvo. Znanstveno publicistično središče. Ljubljana.

Luthar, Oto. 2014. The Land Between. A History of Slovenia. Land Verlag. Frankfurt/M.

Luthar, Oto. 2017. Of Red Dragons and Evil Spirits. Post-Communist Historiography between Democratization and New Politics of History. CEU Press. Budapest.

Maier, Charles, S. 1993. "A Surfeit of Memory? Reflection on History, Melancholy and Denial". History and Memory 5, No. 2.

Medvešček, Gregor. 2010. Mit o NOB. Miti in resnice o narodnoosvobodilnem boju. Društvo za raziskovanje polpretekle zgodovine OZNA. Kapelski vrh. 
Ogrin, Matija. 2016. "Zavezina pričevanja”. Zaveza, No. 100, XXVI. Nova slovenska zaveza. Ljubljana.

Pleterski, Janko. 2007. "O NOB in spravi”, in: Stanovnik, Janez; Grčar, Slavko and Pirnovar, Hardvik (eds.): Narodnoosvobodilni boj v slovenskem narodnem spominu. Slovenski zbornik 2007. GO ZZB NOB Slovenije. Ljubljana.

Radonic, Ljiljana. 2009. Krieg um die Erinnerung. Kroatische Vergangenheitspolitik zwischen Revisionismus und europaeischen Standards. Campus. Frankfurt/M.

Rihar, Lenart. 2016. "Sebevidnost more in razuma". Zaveza, No. 100, XXVI. Nova slovenska zaveza. Ljubljana.

Rihar, Lenart. 2016a. "Dve slovenski stoletji: dvajseto in enaindvajseto". Zaveza, No. 100, XXVI. Nova slovenska zaveza. Ljubljana.

Senegačnik, Brane. 2016. “Trije cilji Zaveze”. Zaveza, No. 100, XXVI. Nova slovenska zaveza. Ljubljana.

Sušnik, Peter. 2016. “Zaveza kot spodbuda”. Zaveza, No. 100, XXVI. Nova slovenska zaveza. Ljubljana.

Snyder, Timothy. 2010. Bloodlands: Europe between Hitler and Stalin. Bodley Head. London.

Troha, Nevenka. 2017. "Slovenia, Occupation, Repression, Partisan Movement, Collaboration, and Civil War in Historical Research". Südost-Europa, Volume 65, No. 2, pp. 334-363.

Tucker, Aviezer. 2008. "Historiographic Revision and Revisionism. The Evidential Difference", in: Michal Kopeček (ed.): Past in the Making. Historical Revisionism in Central Europe after 1989. Central European University Press. Budapest.

Vodopivec, Peter. 2016. Od Pohlinove slovnice do samostojne države. Slovenska zgodovina od konca 18. do konca 20. stoletja. Modrijan. Ljubljana.

Oto Luthar is a member of the Institute of Culture and Memory Studies, Research Centre of the Slovenian Academy of Sciences and Arts.

Mailing Address: Oto Luthar, Znanstvenoraziskovalni center Slovenske akademije znanosti in umetnosti, Novi trg 2, 1000 Ljubljana, Slovenia.

E-mail: oto.luthar@zrc-sazu.si 